\title{
Transport Policy in Aging Societies: An International Comparison and Implications for Canada
}

\author{
R. Mercado, A. Páez, D.M. Scott", K.B. Newbold and P. Kanaroglou \\ Center for Spatial Analysis, School of Geography and Earth Sciences, McMaster University, Canada
}

\begin{abstract}
This paper provides a framework for evaluating and comparing country transport policies to understand the extent to which these are being altered to cope with aging societies. Using the framework, transport policy documents of six countries in the industrialized world were analyzed and compared. A deliberate effort is made in the selection of countries to draw lessons from the comparative evaluation for Canadian transport policy. The paper highlighted the importance of country policy context and motivations in influencing the country's choice of transport strategies and approaches. The paper also proposed a checklist of policy areas encompassing the wider variety of concerns that directly and indirectly impact on older people's mobility. Finally, future policy and research issues on transport and aging are underlined in general and as they relate to Canadian situation.
\end{abstract}

Keywords: Aging, comparative analysis, elderly, mobility, quality of life, transport policy.

\section{INTRODUCTION}

The aging of the population is one of the modern challenges facing most countries and is expected to be increasingly felt over the next two or three decades [1]. It is anticipated that an aging society will have a profound impact on future transport systems so much so that policy movements for its greater recognition in the national agenda have been quite substantial in Europe and North America [2-5]. Also, quantitative analysis and modeling of travel behaviour of the older population are also growing to provide evidence on the travel behaviour of the older group of population to inform policy [6-13].

In recent years, transportation researchers have recognized the need to see the aging and transportation nexus beyond the usual social equity issues of mobility demand provision to embrace a wide range of health, economic, politi$\mathrm{cal}$, and environmental ramifications $[14,15]$. This array of issues is closely related to what transportation researchers have termed Quality of Life (QOL) issues [16] consistent with the World Health Organization/United Nations' framework on "active aging" [17]. There is a widely held belief that today's older people and the baby boomers (which will eventually compose the next generation of older persons) have needs, preferences and concerns markedly different from previous generations [18-20]. While there is yet limited evidence to support this current perception, recent empirical studies have shown that such cohort (or generational) differences are apparent especially in terms of travel needs and behaviour [21-23]. This change in features and lifestyles of older persons (which is undoubtedly linked, in general, to their improved health, greater economic resources and better education) will have significant bearing in terms of mobility satisfaction, safety and other societal issues such as urban

*Address correspondence to this author at the Center for Spatial Analysis, School of Geography \& Earth Sciences, McMaster University, 1280 Main Street West, Hamilton, Ontario, Canada L8S 4K1; Tel: 1.905.525.9140, Ext. 24953; Fax: 1.905.546.0463; E-mail: scottdm@mcmaster.ca sprawl, air pollution, environmental degradation and congestion $[3,15,23]$. Many of these concerns are now being articulated more explicitly to shape national transport policies in the context of an aging society and/or to craft a comprehensive national aging policy that cuts across the various development sectors $[4,5]$.

This paper provides a framework for analyzing country transport policies in relation to population aging issues as well as in making cross-country comparisons. The framework aims to shed light on the extent to which countries are gearing up their respective transport policies in the context of aging societies and what can be done to refine or redefine them. To demonstrate the applicability of such framework, the paper undertook a comparison across six countries in the developed world. The countries used for comparison with Canada include Australia, Japan, Netherlands, UK, and the US - all prosperous and aging countries (Table 1). While no country is expected to fit exactly the Canadian context, the countries possess certain similarities with Canada in terms of government structure (all study countries), economic system (US), law and culture (US, UK, Australia), population and economic geography (Australia) as well as social and environmental orientation (UK, Australia, Netherlands, Japan). The inclusion of Japan in the analysis, in particular, is motivated by an interest in the shape and path of transport policy of a country that has already reached the proportion of older population that most industrialised countries will achieve in at least ten years hence. The study compares land transport policy objectives, approaches and solutions with respect to key economic, financial, social, environmental and technological dimensions and their direct or indirect impact on older people's mobility. The investigation involves policy evaluation of government "white" papers and related official transport policy documents of the respective countries. Independent reports and studies from government, academic or research institutes, international organizations, and consultancy groups are also used to supplement the investigation and to identify gaps in terms of research and policy work. 
Table 1. Population Aging Indicators in Comparative Countries

\begin{tabular}{|c|c|c|c|c|c|c|}
\hline $\begin{array}{c}\text { Indicator/ } \\
\text { Country }\end{array}$ & Canada & US & UK & Australia & NL & Japan \\
\hline \hline $\begin{array}{c}\text { Population } \\
\text { (000's) }\end{array}$ & & & & & & \\
2005 & 32,271 & 299,846 & 60,245 & 20,310 & 16,328 & 127,897 \\
2025 & 37,912 & 354,930 & 65,190 & 24,393 & 16,960 & 121,897 \\
2050 & 42,754 & 402,415 & 68,717 & 28,041 & 17,265 & 102,511 \\
\hline Percent 60+ & & & & & & \\
2005 & 17.8 & 16.6 & 21.2 & 17.8 & 19.3 & 26.4 \\
2025 & 28.0 & 23.8 & 26.5 & 25.8 & 29.2 & 35.8 \\
2050 & 31.9 & 26.8 & 30.1 & 30.2 & 30.7 & 44.0 \\
\hline Percent $80+$ & & & & & & \\
2005 & 3.5 & 3.5 & 4.5 & 3.5 & 3.6 & 4.8 \\
2025 & 5.0 & 4.1 & 5.5 & 5.1 & 5.4 & 10.6 \\
2050 & 10.0 & 7.6 & 9.2 & 9.3 & 10.4 & 15.5 \\
\hline Median Age & & & & & & \\
2005 & 38.6 & 36.0 & 38.9 & 36.7 & 39.1 & 42.9 \\
2025 & 43.0 & 38.3 & 41.5 & 40.8 & 44.1 & 50.5 \\
2050 & 45.3 & 41.1 & 43.4 & 43.4 & 44.2 & 54.9 \\
\hline
\end{tabular}

Note: Figures based on statistics culled from the report entitled "World Population Prospects: The 2006 Revision" prepared by the United Nations (UN) Department of Economic and Social Affairs, http://www.un.org/esa/population/publications/wpp2006/ wpp2006.htm (last accessed September 2007).

The structure of the paper is as follows. The second section briefly describes the general analytic framework and the proceeding sections demonstrate its application. In particular, the third and fourth sections discuss the policymaking context of the countries being studied expounding on their varying institutional structures and policy motivations, respectively. The fifth section highlights and contrasts the articulated transport policy objectives. Next, transport policy approaches and solutions are surveyed and compared. The final section closes the report summarizing the lessons from the countries surveyed, and reflecting on transport and aging issues in general and in Canada.

\section{GENERAL ANALYTIC FRAMEWORK FOR TRANS- PORT POLICY EVALUATION IN RELATION TO AGING ISSUES}

The general analytic framework to evaluate transport policy within and across countries in relation to population aging issues includes three elements: context, content and consequences. The framework could be considered holistic as it not only captures the standing transport and transportrelated policies affecting the older population but also sets them against the policy and institutional framework of each of the countries under investigation. As will be shown in the framework application, such contextual analysis and dissection of policy goals and values are important in understanding why specific transport strategies are adopted over the other and why variations occur across countries. From a policy analyst's perspective, this implies a conscious need to situate existing or proposed policies within the country's framing of the policy problem. The following briefly describes the main elements of the study framework.
Context. Transportation policies are analyzed with respect to the context upon which they were formulated. These include the institutional set-up and policy motivations derived from the country's socio-economic and political circumstances. The institutional analysis surveys and evaluates the country's general government structure and how subnational entities fit into the policy formulation and implementation processes. Moreover, transport institutions are identified and examined in terms of the breadth of mandate and power as well as their interconnections with other public agencies as well as the private sector. Policy motivations are analyzed in terms of the country's transport framework messages in terms of their end goals. For a cross-country comparison, these end goals can be analyzed in terms of distinct (i.e. particular to a country), convergent (i.e. shared by all of the study countries/regions) and divergent (i.e. contrasting or conflicting with each other) policy end goals or values.

Content. Policy contents are summed up in terms of policy objectives, approaches and solutions. The policy objectives can be classified in different ways to allow for comparison among selected countries or regions. This paper classified the transport policy objectives via the main elements of sustainable transportation: economic, social and environmental sustainability. Within this broad classification, subcategories are made to make more in-depth country comparisons. Policy approaches and solutions are presumably translations of the country's policy objectives. Given the variety of these policy and program instruments there is a need to put them together into general themes especially as they directly or indirectly impact on older people's mobility. This paper introduced six policy areas where these approaches and solutions identified by the study countries can fall under. These are 1) the general policy on preference for various transport modes (private car, public transit, walking, cycling, etc.) and the economic instruments (i.e. programs, infrastructure, technology) that promote them; 2) current stock and investments on transportation infrastructure and systems; 3 ) the linkage between transportation and land use planning as it impacts on the living environment of older people; 4) research and technology applications that improve the travel mode and environment; and 5) institutional reforms and policy management initiatives that will enhance and help achieve program formulation and implementation. The set of policies that have direct and indirect consequence to aging issues can be assessed as to the scope and level of detail, providing a survey of the wide variety of measures that are being taken by the study countries. This set of aging-related policies can also be used in benchmarking sub-national transport policies as they affect elderly mobility [24].

Consequence. An investigation of the policy outcomes and performance of a set of policy or specific policy solutions should be an important challenge for research or policy analysis. Often, policy intentions can be undermined by the actual implementation of adopted program approaches and solutions bringing about poor outcomes or unintended consequences. Such analysis will provide the basis for finetuning or (re)defining transport policy so that they will achieve the desired goals or values. There are a host of policy analytic methods both qualitative and quantitative methods to measure policy outcomes and impact. Some require the collection of new information to allow for the development of indicator variables or performance measures em- 
ploying statistical or more sophisticated models and tools. In some others, they rely on or infer from available information and complementing the same with information gathered or derived from program service providers, target groups and beneficiaries, as in the case of case study reports. Given its program specificity and complex nature, a demonstration of this element of the framework is not shown in the present paper. Thus, the proceeding sections, provide an application of the framework only with respect to the first two major elements of the evaluative framework, namely context (institutional structure and policy motivations) and content (transport policy objectives, approaches and solutions).

\section{INSTITUTIONAL STRUCTURES}

Table 2 provides at a glance the general structure of government and the main transport institutions of the countries under comparison. Apart from the US, all the countries under study are constitutional monarchies with parliamentary forms of government. The US, however, shares with Canada and Australia a federal system that provides for relative autonomy of the provinces or states and territories.

All countries have a ministry or department responsible for transport concerns. However, because of the need for policy coordination to integrate concerns of the environment, regional development and land-use policy, some countries have either engaged in a reorganization of their transport agencies to include these sectors, or have involved in a more systematic way other departments/ministries in shaping national transport policy.

To illustrate, in Japan, as part of the government-wide reform efforts of 2001, four national government agencies, namely, the Ministry of Transport, Ministry of Construction, Agency of Land and the Agency of Hokkaido Development, were merged to form the present Ministry of Land, Infrastructure and Transport (MLIT). The consolidation has al- lowed for the establishment of a premier public works authority that is hoped to make transport policy consistent and to address in a more coordinated fashion the "effective response to an aging society; solutions to environmental problems; building of an advanced information society; and domestic response to globalization" [25]. In the case of the Netherlands, the coordination of spatial planning with spatially relevant policies including transportation, agriculture and regional economic development has been second nature to Dutch governance approach. Its national spatial plan (National Spatial Strategy) provides the framework for the formulation of the national policy documents relating to the cited sectors. Thus, Dutch transport policy is effectively a translation of the national spatial plan [26, 27]. The national authorities set the general spatial framework and policy while local governments are responsible for land-use planning and implementation. For instance, the ABC location policy (i.e. policy aimed at reducing avoidable car mobility and ensuring access to economic centers) is espoused in the national plan as a tool for sustainable development. However, action plans to implement such policy is prepared by local governments for submission to and funding by national authorities. In Canada, transport policy in recent years has taken into account the concerns of the environment and goals for sustainable development. Given this mindset, there have been conscious efforts by Transport Canada to undertake initiatives for closer coordination especially with environment and health ministries.

The institutional set-up for transport policy formulation and implementation mirrors the general governance structure of the countries under study. In general, there exists a strong correlation between the level of decision-making and the degree of participation of the various transport policy actors (central authorities, sub-national governments, industry, community, people's organizations, etc.) in these countries. The more central decisions are made, the lesser the degree of

Table 2. General Governance and Major Transportation Institutions in Comparative Countries

\begin{tabular}{|l|l|l|l|}
\hline \multicolumn{1}{|c|}{ Country } & \multicolumn{1}{|c|}{$\begin{array}{c}\text { Overall Government } \\
\text { Structure/System }\end{array}$} & \multicolumn{1}{c|}{$\begin{array}{c}\text { National Transport } \\
\text { Institution/s }\end{array}$} & \multicolumn{1}{c|}{$\begin{array}{c}\text { Sub-National } \\
\text { Entities }\end{array}$} \\
\hline \hline Japan & $\begin{array}{l}\text { Constitutional Monarchy } \\
\text { Parliamentary System } \\
\text { Unitary State }\end{array}$ & $\begin{array}{l}\text { Ministry of Land, } \\
\text { Infrastructure and Transport (MLIT) }\end{array}$ & $\begin{array}{l}\text { Metropolitan district (Tokyo) } \\
\text { Urban prefectures (2) } \\
\text { "Rural" prefectures (43) }\end{array}$ \\
\hline UK & $\begin{array}{l}\text { Constitutional Monarchy } \\
\text { Parliamentary System } \\
\text { Multinational Unitary State } \\
\text { England, Wales, Scotland, } \\
\text { Northern Ireland) }\end{array}$ & $\begin{array}{l}\text { Department of Transport } \\
\text { Office of Deputy Minister } \\
\text { (Local Government and } \\
\text { Regions/Social Exclusion Unit) } \\
\text { Department of Environment }\end{array}$ & $\begin{array}{l}\text { Regional Govt. (3) } \\
\text { Greater London Authority } \\
\text { Regional Devt.Agencies (12) } \\
\text { Non-metro counties, unitary authorities, coun- } \\
\text { cils }\end{array}$ \\
\hline Netherlands & $\begin{array}{l}\text { Constitutional Monarchy } \\
\text { Parliamentary System }\end{array}$ & $\begin{array}{l}\text { Ministry of Transport, Public Works and Water } \\
\text { Management (V\&W) }\end{array}$ & $\begin{array}{l}\text { Special Regions } \\
\text { Provinces (12) } \\
\text { Municipalities }\end{array}$ \\
\hline US & $\begin{array}{l}\text { Republic } \\
\text { Presidential - Congressional } \\
\text { Federal State }\end{array}$ & $\begin{array}{l}\text { Department of Transportation } \\
\text { (USDOT) }\end{array}$ & $\begin{array}{l}\text { Metro Planning Orgs (MPOs) } \\
\text { States(50) } \\
\text { Municipalities, counties, townships (39,000) } \\
\text { Special local govt. (44,000) }\end{array}$ \\
\hline Australia & $\begin{array}{l}\text { Constitutional Monarchy } \\
\text { Parliamentary System } \\
\text { Federal State }\end{array}$ & $\begin{array}{l}\text { Ministry of Transport and Regional Services } \\
\text { Ministry of Local Government, Territories and Roads }\end{array}$ & $\begin{array}{l}\text { States (6) } \\
\text { Territories (2) } \\
\text { Local Governments (722) }\end{array}$ \\
\hline Canada & $\begin{array}{l}\text { Constitutional Monarchy } \\
\text { Parliamentary System } \\
\text { Federal State }\end{array}$ & Transport Canada & $\begin{array}{l}\text { Provinces (10) } \\
\text { Territories (3) } \\
\text { Municipalities (3700) }\end{array}$ \\
\hline
\end{tabular}


participation of the various stakeholders in the formulation and implementation of policy decisions.

All countries, except the US, are constitutional monarchies and thus state control is expectedly evident. However, centralization occurs mainly in unitary states such as Japan, the UK and the Netherlands. In these countries, transport planning and investments are determined nationally and lower levels of government serve mainly as an extension arm of the national government. While these nations are now veering towards a more decentralized regime, provincial or state sub-national plans still have to conform to the national policy direction if they are to be granted government funding for costly infrastructure projects. In contrast, US, Canada and Australia, being federal states, are more decentralized in that most urban planning and infrastructure provision are provincial or state-level responsibilities. However, the national government is still involved in either the implementation of transport projects with provinces, or in the administration of federal funds and programs of which provinces/states compete for funding. For instance, in Canada, the federal government (Transport Canada) provides funding to the provinces and territories for primary and secondary highways as well as access roads while at the same time, partners with them in the implementation of transport programs and projects under a cost-sharing agreement [28]. In the US where the states are largely responsible for state-wide transport plans and programs and coordination of regional plans with the Metropolitan Planning Organizations (MPOs), federal role in transport is indirect through administration of funding and funding-related requirements. The USDOT administers federal funding programs mostly carried out by its two departments, namely, the Federal Highway Administration (FHWA) which is responsible for highway and streetrelated programs and funding and the Federal Transit Administration (FTA) for mass transit programs. The funds come from the Highway Trust Fund (with highway and transit components) and other funds distributed to the states based on an adopted formula.

There have always been debates and clamour for greater local control in transport governance in both centralized and decentralized governments [29, 30]. However, given the strategic role of transportation in terms of addressing social, economic and political issues including national security, a more coordinated policy structure has often been the preferred arrangement. To realize such policy structure, the practice in most countries heads towards greater deregulation of commercial transport and decentralization of transport policy, but more in the direction of administrative versus fiscal independence. The central government in most of the study countries, even in the decentralized ones, retains some degree of fiscal control over financial resources in terms of revenue collection and allocation in order to further national interests. Funds that could be used for transportation programs and projects are released to lower levels of government on the condition that they meet or are consistent with the national or regional objectives and plans based on policy and economic criteria. In most of the study countries, national government funds for transport programs and projects, which come from general government revenues (including fuel taxes), are distributed through yearly government allocations. For example, in the US, there are funds earmarked for transportation spending and administered by the FHWA and
FTA. Also the MPOs have a strong recommendatory role in selecting projects for federal funding in urban areas with over 200,000 people. Recently in Australia, a national transport plan ("AusLink") has been put in place, which would have implications on the magnitude and the manner of fund disbursement to states and territories existing currently [31, 32].

\section{POLICY MOTIVATIONS}

Given the variety in economic, social and political circumstances of the countries under study, it is hardly surprising to find distinct visions and thrusts as well as diverging mindsets in their policy directions. On the other hand, it is interesting to note that these countries are in so many respects in unison in terms of policy end-goals. Table 3 encapsulates these nuances in policy motivations and, for the purpose of comparison, classifies them in terms of unique (distinct), common (converging) and differing (diverging) framework messages.

Distinct. Population aging is a common thread in the overall policy framework in Japan. A basic law (Law No. 129, 1995), entitled "The Basic Law on Measures for the Aging Society", was enacted in order to establish a clear objective, direction and measures to guide the national government and the public in dealing with an aged society. It is for this reason that demographic aging finds centrality in Japan's transport policy as depicted in the introductory note of its white paper on transport:

"Today, Japan is facing major changes, never before seen. In the next few years, total population will begin to decline, led by the major nations.... we are experiencing an unprecedented increase in the senior population and a decline in the youth population. The environment surrounding Land, Infrastructure and Transport administration grows ever more severe. Not only do we expect the financial limitations on social capital development will grow stronger with increases in expenditures for social security, the aging of social investment inventory itself is progressing rapidly, and the necessary maintenance and replacement costs to deal with this will place limits on the power to make investments in new fields. Under such conditions, administration is not enough merely to follow various changes; we must anticipate future changes caused by these major demographic changes and positively fulfill our role in the construction of an active Japan economy and society. Before the great wave of demographic change inundates us, we must pursue the necessary socio-economic infrastructures and transportation policies to strengthen Japan's international competitiveness and, taking these changes as rather an opportunity, try to realize a bountiful and comfortable national lifestyle, properly applying selection and concentration to the limited resources given to land, infrastructure and transport administration..." [33].

A noteworthy perspective in Japan's transport policy is seeing an aging society from a positive light ("opportunity"), a departure from the usual problematic stance. Dealing with demographic changes in Japan sets the platform for harnessing the resources and technologies that are available to create a living environment that will make the country more competitive while addressing the needs of their older population. The basic precept is that what is good for the elderly will also be for all ages and for the nation as a whole. 
Table 3. Key Messages/Policy Motivations of Country Policy Frameworks

\begin{tabular}{|c|c|c|c|}
\hline $\begin{array}{c}\text { Country Policy Framework } \\
\text { Document }\end{array}$ & Distinctive & Converging & Diverging \\
\hline $\begin{array}{l}\text { Japan } \\
\text { White Paper on Land, } \\
\text { Infrastructure and } \\
\text { Transport in Japan }\end{array}$ & $\begin{array}{l}\text { Demographic aging as "opportunity" for trans- } \\
\text { port policy to activate economy and society } \\
\text { Towards seamless transportation }\end{array}$ & $\begin{array}{l}\text { Population aging } \\
\text { Economic/Global } \\
\text { Competitiveness Environment } \\
\text { Safety } \\
\text { PPPs }\end{array}$ & $\begin{array}{l}\text { Efficient, effective and } \\
\text { accessible public trans- } \\
\text { port service and } \\
\text { infrastructure }\end{array}$ \\
\hline $\begin{array}{l}\text { UK } \\
\text { White Paper on the } \\
\text { Future of Transport } \\
\text { "A New Deal for Trans- } \\
\text { port: Better for Everyone" }\end{array}$ & $\begin{array}{l}\text { Transport policy focus on health and environ- } \\
\text { ment "Integrated transport policy" }\end{array}$ & $\begin{array}{l}\text { Environment } \\
\text { Safety } \\
\text { Expand transport alternatives to car } \\
\text { PPPs } \\
\text { Population aging }\end{array}$ & $\begin{array}{l}\text { Focus on public transport } \\
\text { Reduction of car use }\end{array}$ \\
\hline $\begin{array}{l}\text { Netherlands } \\
\text { National Traffic and Trans- } \\
\text { port Plan 2004-2020 }\end{array}$ & $\begin{array}{l}\text { Pricing policy takes central position in policy } \\
\text { Decentralization of traffic and transport policy } \\
\text { Shift from supply-oriented thinking to client- } \\
\text { oriented thinking }\end{array}$ & $\begin{array}{l}\text { Environment } \\
\text { Safety } \\
\text { Expand transport alternatives to car } \\
\text { PPPs } \\
\text { Population aging }\end{array}$ & $\begin{array}{l}\text { Respect for mode choice } \\
\text { of the public/ } \\
\text { No one-sided solution to } \\
\text { car } v s \text { public transit }\end{array}$ \\
\hline $\begin{array}{l}\text { US } \\
\text { Strategic Plan 2003-2008 } \\
\text { "Safer, Simpler, Smarter } \\
\text { Transportation Solutions" }\end{array}$ & $\begin{array}{l}\text { World-class transportation security system } \\
\text { Transportation responsive to defense needs } \\
\text { Changing demographics (aging and immigration) } \\
\text { to alter transport requirements and governance }\end{array}$ & $\begin{array}{l}\text { Safety } \\
\text { Economic/Global competitiveness } \\
\text { Environment } \\
\text { PPPs } \\
\text { Population aging }\end{array}$ & $\begin{array}{l}\text { Bring about important } \\
\text { changes in all transport } \\
\text { modes at the same time }\end{array}$ \\
\hline $\begin{array}{l}\text { Australia } \\
\text { Auslink White paper } 2004 \\
\text { "Building Our National } \\
\text { Transport Future" }\end{array}$ & $\begin{array}{l}\text { Better land use planning } \\
\text { National and interregional connectivity } \\
\text { - focus on strategic network of transport corri- } \\
\text { dors }\end{array}$ & $\begin{array}{l}\text { Economic/Global competitiveness } \\
\text { Environment } \\
\text { Safety } \\
\text { PPPs } \\
\text { Demographic trends }\end{array}$ & $\begin{array}{l}\text { Public transport } v s \text { car is } \\
\text { State/Territory issue }\end{array}$ \\
\hline $\begin{array}{l}\text { Canada } \\
\text { Vision/Strategy for Sus- } \\
\text { tainable Transportation } \\
\text { "StraightAhead: A Vision } \\
\text { for Transporation in Can- } \\
\text { ada }\end{array}$ & $\begin{array}{l}\text { Challenge of a "scheduled economy" in tandem } \\
\text { with environmental imperatives } \\
\text { Research and skills development to support } \\
\text { innovation }\end{array}$ & $\begin{array}{l}\text { Safety } \\
\text { Economic/Global competitiveness } \\
\text { Environment } \\
\text { PPPs } \\
\text { Population aging }\end{array}$ & Modal neutrality \\
\hline
\end{tabular}

There are three interrelated policy directions in this regard. First is the development of "focused and efficient social capital infrastructure". This translates to infrastructure investments that will heighten economic productivity and international competitiveness while at the same time ensure that these infrastructures promote safety and peace of mind especially to its senior citizens whose number is on the rise and are vulnerable especially in times of disaster. Among the strategies identified to realize this is the adoption of a transportation policy that emphasizes competition and cooperation between and among the public sector, industry and transport operators as well as the installation of a seamless public transportation. The second policy direction is increased social participation of women and seniors. In this connection, the importance of building barrier-free passenger and traffic facilities, vehicles (railway cars, buses, passenger ships and airplanes) as well as in home and living environments such as parks, buildings and passageways including the participation of seniors in the transport industry's work force are emphasized. Moreover, the application of innovative technologies and services such as the IC card in public transportation and daily support transport services are very well recognized. Thirdly, the need to maintain and activate the vitality of regions and cities is important from the perspective of a declining population. A large part of this effort is the promotion of a global tourist strategy that encourage foreign visitors to Japan by building a traffic network that will support regional tourist destinations and activities. Such effort will not only increase the traveling population but would also provide opportunities for new transport structures especially for transportation-deprived areas that will "insure traffic for daily life".

In the case of the UK's transport policy framework, health and environment take center stage. There has been an alarming concern that privatization and deregulation that have dominated transport policy for the past 20 years resulted in the decline of public transit, damaging people's health and the wider environment. Thus, an "integrated transport policy" is at the heart of the nation's transportation pursuits for health and environmental reasons:

"We cannot go on as we were, trying to build more and more new roads to cope with growing levels of traffic. Instead, we must have: more real transport choice, better buses and trains, a better deal for the motorist, better maintained roads, a railway working for the passenger, more money for public transport, more freight on the railway and safer and more secure transport systems. These new policies put transport at the heart of our priorities and show our commitment to develop better places to live and work"...".Developing an integrated transport policy represents a major shift in direction. We don't just want to stop traffic problems getting worse; we actually want to make things better for people and goods on the move...[34]. 
"Integrated transport policy" also addresses one of UK Government's central objectives which is tackling social exclusion. Mainstreaming the transport needs and requirements of the different social groups including the older people is a key policy element that will promote a transport system that is fair, efficient, and safe.

The policy framework in the Netherlands is also about choices. However, it sees mobility choice as part of the modern society but the user has to bear the costs for such freedom [35]. In this respect, government interventions will primarily rely on market forces via pricing policy (e.g. paying for use of car $v s$ ownership, etc.). The Netherlands, with a tradition of centralized transport policy-making, sees the need to decentralize its operations by giving greater authority to sub-national entities to effect a more "intelligent and efficient organisation" to implement the national plan.

Of all the countries, the US has the highest concern for safety in its transportation policy framework [36]. The repercussions of the 9/11 terrorist attacks gave USDOT an urgent task to ensure safety and security in all modes of transport. Its mandate to establish a world-class transportation system will, thus, require the sector to be on the leading edge of technology. The US policy framework also identified future shapers of transport policy. One of these is changing demographics (aging and immigration), which is reckoned to alter future transport requirements and governance - a shift towards increased state and local control of transportation.

Australia's current transport policy framework focus on national and interregional connectivity triggered by the current "parochial and ad-hoc system" that is seen as an impediment to national competitiveness. It should be realized that prior to the recent adoption of AusLink, Australia did not have a national urban transportation strategy and that state legislations and regulations in the movements of transport between states have been seen as causing inefficiency to the transport system. Land-use planning is a key to the present strategy and for which a "National Charter of Integrated Land-use and Transport Planning" has been forged to solidify the commitment of all policy actors.

In Canada, one of the most challenging tasks is reconciling the needs of a highly efficient "scheduled economy" (requiring highly reliable, tightly controlled, just-in-time transportation services) while addressing the environmental costs of such efficiency. This tension will need clear and innovative policy guidance from the national government and collaboration with various stakeholders. Skills development, research and development and exploitation of new technologies are given special importance in the overall transport vision viewing transportation as a knowledge-based sector.

Convergence. Economic growth and international competitiveness are paramount aspirations of all countries reflecting the importance of transportation especially in a global economy. Safety is also a common concern, which refers to both national security (from terrorism or calamities) as well as to personal safety in travel modes with the aim to reduce fatalities and accidents. Environmental impacts in terms of congestion and vehicle emissions affecting health and climate change are underlined in country frameworks. All countries have explicitly recognized demographic changes, particularly the aging of the population as a key factor shaping the transport system in the long-term - especially its implications to accessibility, equity and transportation infrastructure demands - albeit in varying degrees. The level of this recognition is highest in Japan where aging and competitiveness are seen as complementary forces. In Canada, accessibility of transport for older people (along with remote regions and the disabled) is part of the seven principles of transport policy. The US, the UK and the Netherlands view the challenge as part of the issues relating to social inclusion and quality of life. Finally, the importance of publicprivate partnerships (PPPs) at all government levels in terms of project implementation, innovation and funding are emphasized in every country's transport frameworks.

Divergence. An evident difference in the policy frameworks of the comparative countries is the attitude placed on car use versus public transit. This aspect is significant as the policy choice on travel mode is critical in influencing investment decisions as well as the application of economic instruments that will impact on older people's mobility. It may be argued that the policy bias in mode preference could be the result of the existing transport network and general travel preferences of people in these countries (i.e. Japan downplays cars because it has a very dense train network and a cultural habit to travel by train or bus, compared to the US or Canada where personal mobility is often referred as using a car). However, it could also be explained by a deliberate radical policy choice as in the case of the UK. The UK has the most forceful policy of promoting less use of cars by making public transit better and more competitive. It presupposes that while private cars are expected to remain important in ownership and usage, more efficient and reliable public transport will encourage more people to use it and thus provide a real transport choice. Public transit investments plans are articulated in detail with clear and concrete goals and outcomes. It should, however, be noted that such policy intent has met difficulty in implementation but nevertheless influenced succeeding long-term policy on transport [37].

Japan also has a comprehensive plan for public transit but the motivation for its improvement and accessibility is largely premised not in terms of reduction of or competition with car usage but allowing for the development of social infrastructure that would be responsive to an aging society. Transport policy seems to be hushed on car use although mention has been made with respect to developing advanced safety vehicles. In the Netherlands both pull measures (making alternatives to the car more attractive) and push measures (making car less attractive) are adopted. Since the latter measures are deemed lagging behind the former, there are now serious efforts to adopt and implement pricing policies with more vigour to balance the policy package. As mentioned earlier, the new Dutch transport policy downplays the negative connotation of car mobility and embraces it as part of modern society. However, the so-called "balanced policy package" attempts to correct the bias in favour of car use not only by improving existing infrastructure for non-car modes but also by introducing pricing policy in the form of charges for the use of a car replacing the fixed charges on car ownership (i.e. motor vehicle tax, personal car and motorcycle tax, excise taxes on fuel) currently enforced. The Mobility Policy Document articulates well the rationale for such pricing policy, to wit: 
"Drivers already pay for possession and use of cars in various ways...the manner in which drivers currently pays, however, is not adequate stimulus for conscious mobility behaviour. Road users make their own mobility choices and must therefore also be given a better means to feel and bear responsibility for the consequences of the choices they make. New ways to pay for mobility will stimulate drivers to consciously and responsibly consider whether to use a car and when to use it: the user pays..."

Canada and the US share a common attitude of modal neutrality that provides a level playing field for all modes. In the US, passage of the Intermodal Surface Transportation Efficiency Act (ISTEA) and the Transportation Equity Act for the $21^{\text {st }}$ Century (TEA 21) was instrumental in enhancing non-motorised modes (walking, biking) and transit through huge increases in funding and the general change in the mindset of transport planners and professionals [38]. Gertz [38] underlined the fact that prior to these legislations, there has never been federal money available for pedestrians, bike paths, and transit improvements. In Canada, the search for balance between efficiency and other goals remains a challenge. Sustainable development has become a paramount goal in all levels of Canadian government and the adoption of alternatives to the car such as walking, biking and using public transit is seen as a more sustainable form of urban mobility. But this recognition has not seen much translation yet. The report of the Canada Transportation Act Panel sums up the current situation:

"The fact that Canadians are not adopting these alternatives to a greater extent- especially when they would often be cheaper in terms of out-of-pocket costs-shows how much users value the service qualities they get from cars and trucks: speed, convenience, flexibility, reliability and comfort. But it also reflects the fact that road users do not have to cover the whole cost of road use, because of the way governments fund road infrastructure, and because most users do not have to deal personally with some of the unwelcome social effects. If they had to do so - if road users were charged directly on each trip for the cost of maintaining the road network, as well as for the costs of congestion, environmental damage and accident risks that their road use impose on others - it seems likely that their choices would change and more of the alternatives would be used. This possibility poses crucial policy issues for governments at all levels" [39].

In the case of Australia, the federal government left the policy decision to states and territories. However, it espouses the view that walking and cycling should be promoted through land-use planning and provision of transport infrastructure to address the national problem of obesity, which affects more than half of the Australian population. This is also reflected in its National Land-use Charter where widening of transport mode choices is seen to increase accessibility and reduce vehicle demand and impacts.

\section{TRANSPORT POLICY OBJECTIVES}

The policy motivations discussed above find translation in the specific policy objectives for transport. Table 4 conveniently summarizes the transport objectives into three categories - economic, environmental and social/political - encompassing three key elements of sustainable transportation systems. Finding the right balance among these three elements is the fundamental policy challenge in these countries.

Each country has expressed differently each of these generic objectives to reflect their varying circumstances. For instance, in terms of economic objectives, Japan, the US and the Netherlands place emphasis on global integration of transport given the role placed on transport in their respective competition policies. While this is also true for the rest of the countries under study, more pressing in-country (urban and inter-urban) concerns of congestion relief and freight bottlenecks surface in most instances in Canada, Australia and the UK in view of the anticipated rise in transport activities resulting from expanded trading and business activities. In terms of environmental objectives, the US and Canada emphasize commitment to environmental responsibility - sharing a strong resolve to bring balance to economic growth without undermining its responsibility to preserve environmental quality. The other countries frame the environmental objective in terms of either problems needing solutions or outcomes desired or valued.

With respect to the former, Australia sees the need to address the social and environmental costs of growth in transport especially congestion. In the case of the UK and the Netherlands, the objectives are articulated in terms of end states of improved quality of life and better living environment. In Japan, such living environment has to be one that offers peace of mind especially to its seniors. Safety and social inclusion are very high on the agenda in the countries under study. Social inclusion is explained in the narrow context of more accessible transportation and/or in broader social and human concerns such as equity and potential for social participation.

\section{TRANSPORT POLICY APPROACHES AND SOLU- TIONS}

Transport objectives become more diverse when translated to more specific approaches and solutions. Table 4 takes stock of the various approaches, solutions and instruments of the various countries and classifies them according to policy areas that would directly or indirectly impact on the mobility of older people. They were classified to fall under five major policy areas. These include modal choices, transportation infrastructure, systems and services, technological solutions, land-use and living environment and institutional and policy reforms.

The first set concerns travel mode choice and the economic instruments that promote them. Countries seem to adopt more incentives or disincentives to promote their favoured mode choice. It should be mentioned that although most countries have assumed an accommodationist approach to mode choice, transport solutions that promote public transit are considerable. As shown in Table 5, all the study countries have recognized the need to improve public transit and other alternative modes such as walking and using bicycles by adopting specific measures, which have basis on both safety and sustainability standpoints. Of all the study countries, the UK has shown the most aggressive stance to give public transit and other alternative modes of travel a greater 
Table 4. Comparative Matrix of Standing Transport Policy Objectives by Country and Policy Themes

\begin{tabular}{|c|c|c|c|}
\hline Country/Theme & Economic & Environment & Social/Political \\
\hline Japan & $\begin{array}{l}\text { Enhance global competitiveness } \\
\text { Ensure smooth transportation } \\
\text { everywhere }\end{array}$ & $\begin{array}{l}\text { Achieve environmentally friendly trans- } \\
\text { portation } \\
\text { Develop living environment that offers } \\
\text { peace of mind to seniors }\end{array}$ & $\begin{array}{l}\text { Ensure safety (personal and national) } \\
\text { Deal with graying society }\end{array}$ \\
\hline UK & $\begin{array}{l}\text { Better planning for develop- } \\
\text { ment, land-use, transport and } \\
\text { housing }\end{array}$ & $\begin{array}{l}\text { Better protection for the environment } \\
\text { Better places to live } \\
\text { Better buses } \\
\text { Better trains }\end{array}$ & $\begin{array}{l}\text { Better safety and personal security } \\
\text { Fairer, more inclusive society }\end{array}$ \\
\hline Netherlands & $\begin{array}{l}\text { Strengthen the economy and } \\
\text { international competitive posi- } \\
\text { tion }\end{array}$ & Improve quality of life and environment & $\begin{array}{l}\text { Accommodate need for mobility } \\
\text { Improve safety and security - reduce chance of } \\
\text { damage }\end{array}$ \\
\hline US & Global connectivity & Environmental stewardship & $\begin{array}{l}\text { Ensure safety and security - save lives, reduce } \\
\text { accidents and secured from terrorist attacks } \\
\text { Address mobility - congestion and accessibility } \\
\text { (inclusiveness) }\end{array}$ \\
\hline Canada & $\begin{array}{l}\text { Efficient and safe movement of } \\
\text { people and goods (well- } \\
\text { integrated transportation sys- } \\
\text { tem) }\end{array}$ & Respect for environment & $\begin{array}{l}\text { Highest practicable safety and security of life and } \\
\text { property } \\
\text { Reasonable access to national transportation system } \\
\text { for remote regions } \\
\text { Accessibility and social inclusion }\end{array}$ \\
\hline
\end{tabular}

edge over the private car through the adoption of tough economic instruments. However, only the commitment to the increasing use of these instruments and not the specific pricing and taxation measures are discussed in the policy document. Reports indicated concerns that the UK government is seen as being "anti-car" but the Transport Minister emphasized the need for radical change in transport policy [40]. The 1998 Plan has met problems in implementation in view of institutional factors (departmental organizations and Cabinet reshuffles) as well as funding [37]. In the UK 2004 Transport White Paper "The Future of Transport: a network for 2030" [41], the focus of achieving balance between different modes of transport was reiterated with congestion pricing, bus priority measures and pedestrianisation of town and city centres as the policies to make it happen. It delegated to local authorities the implementation of the more radical transport policies including road pricing and congestion charging. Meanwhile, the UK government committed to sustained public spending increases for transport up to 2015 building on the efforts made based on the 1998 plan [41].

In the Netherlands, economic instruments are spelled out in the form of road user charges, a switch from car ownership taxation. It should be noted, however, that in all countries, there is very little articulation, if any, of the development of alternative mobility for older persons who prefer to cut down on driving or who have to stop driving in view of health reasons and/or license regulations. This perspective is perhaps an important argument for a more serious consideration of better public transit system and the development of more innovative transport services now and in the near future.

The second set of solutions relate to investments on transport infrastructure systems and services. Investments that may have bearing on older people's mobility include improvements in modal integration and road design. While most of these investments cater to the general population there are those that are designed to specifically meet older people's mobility needs. This is especially highlighted in the case of the US, Japan and the Netherlands where services are provided to enhance road design for elderly pedestrians and drivers as well as to improve transit services for growing elderly tourists and travelers.

The third set of program solutions comprises technological advances that improve the car or public transit. Again, this is reflective of the country's orientation with respect to mode choice. For instance, the UK's investments on technological advances focus more on modernizing buses and railways than on private cars as the rest of the countries do. Technological solutions to vehicles are prompted by a desire to improve efficiency and safety, as well as to achieve environmental outcomes- that is, better air quality and reduction in greenhouse emissions. To meet these challenges, technological solutions are directed towards better vehicle design that answers safety and comfort needs, improvements in fuel and vehicle technology, and developments in information technology. It is interesting to note that the development of Intelligent Transportation Systems (ITS) is hoped not only to generate information for improving the transportation system but also there are efforts particularly in US, Japan and UK to use these technologies in order to aid pedestrians and public transport users. These advances will benefit all and especially older commuters.

Fourth, the linkages between transportation, land-use and living environments have been emphasized in Japan, the UK, the Netherlands and Australia. This seems to be particularly 
Table 5. Comparative Transport Policy Approaches and Solutions Impacting on Elderly Mobility

\begin{tabular}{|c|c|}
\hline Policy Area & $\begin{array}{l}\text { Approaches/Solutions/Instruments } \\
\text { Symbols: J=Japan, UK=UK, N=Netherlands, A=Australia, US=USA, C=Canada }\end{array}$ \\
\hline \begin{tabular}{l}
\multicolumn{1}{c}{ Others } \\
(Walking/Biking/ \\
Special Services \\
Schemes)
\end{tabular} & $\begin{array}{l}\text { Reduce car use through pricing and taxation (UK) } \\
\text { Shift from fixed car charges to charges dependent on vehicle use (distance and time of day charging) (N) } \\
\text { Strict enforcement of driving laws (N, US); seatbelt laws (US) } \\
\text { Better driving education (N) } \\
\text { Special policy focused on drivers "who are getting on in years" (N) } \\
\text { Increase modal share of public transport through market-oriented approach (N) } \\
\text { Develop a reliable and financially viable intercity passenger rail network (US) } \\
\text { Put greater emphasis on public transit infrastructure projects (C) } \\
\text { Towards seamless transportation system (logistics, ticketing, information) (J) } \\
\text { Single travel ticket (N) } \\
\text { Barrier free transit (railway cars and low-floor buses) and facilities (stations, bus stops) (J, UK, US) } \\
\text { Modern design and better services (UK) } \\
\text { Government investment in rail, tram and bus infrastructure with quality service (N) } \\
\text { Accessibility criterion for new city buses (N) } \\
\text { Full accessibility for bus by } 2010 \text { and rail equipment by } 2030 \text { (N, US) } \\
\text { Scheduled bus service deregulation and liberalization of market entry (reverse onus system (C) } \\
\text { IC or smart Card in public transport (J, N) } \\
\text { Bicylce storage spaces in rail stations (N) } \\
\text { New transport services in areas w/o public transport (J) } \\
\text { Formulate national action plan on cycling and walking (UK) } \\
\text { Overcome infrastructure barriers (UK, US) } \\
\text { Promote walking and cycling through land use planning (A, US) } \\
\text { Creative alternatives to traditional individual transportation for elderly with disabilities and disabled (US) } \\
\text { Public transport subsidies and fare schemes (UK) } \\
\text { On demand bus (J) } \\
\text { Shared taxis UK) } \\
\text { City car clubs (UK) } \\
\text { Encourage public involvement to develop transport solutions that support community needs (US) }\end{array}$ \\
\hline $\begin{array}{l}\text { Transport Infrastructure/ Systems and } \\
\text { Services }\end{array}$ & $\begin{array}{l}\text { Move to a more integrated transport system (C, A, US) } \\
\text { Encourage and facilitate intermodal transportation planning worldwide (US) } \\
\text { Given growth of elderly traveling for leisure, adaptation of transport services in international transit and } \\
\text { destinations (US) } \\
\text { Seamless journey (J, UK) } \\
\text { Installation of "essential recognisability features" (road, speed limit) (N) indicators for crosswalks (J) } \\
\text { Residential areas with } 30 \mathrm{~km} / \mathrm{h} \text { speed limits (N) } \\
\text { Improved road safety features such as enhanced signage in view of aging (US) }\end{array}$ \\
\hline $\begin{array}{l}\text { Technological Solutions } \\
\text { Vehicle Design }\end{array}$ & $\begin{array}{l}\text { Advanced safety vehicle - car (J, N) } \\
\text { R \& D for car model for people with limited mobility (J) } \\
\text { Encouragement of technological innovations through fiscal incentives (N) } \\
\text { Consideration of elderly in designing and building vehicles (US) } \\
\text { Electronic toll collection (ETC) system (J, N, US) } \\
\text { ITS to aid pedestrians (J) } \\
\text { R \& D in transport telematics application (ITS) related to public transport (UK) } \\
\text { Sensors placed on vehicles and infrastructure to analyse traffic flows, behavior emissions (N) } \\
\text { ITS for global connectivity at key transfer points, corridors and border crossings (US) } \\
\text { Develop an ITS R\&D plan (C) } \\
\text { Development and Promotion of Fuel Cell technology (J, US) } \\
\text { Development of cleaner, quieter and fuel-economical vehicle technologies (fuel cell and and bio-fuel) (N, } \\
\text { A) } \\
\text { Promote hybrid cars and motorcycles (N) } \\
\text { Encourage the transition to hydrogen economy through R\&D of advanced vehicle technologies (US) } \\
\text { Stimulate demand for new, more fuel efficient vehicles akin to } \\
\text { Energy Star system (C) } \\
\text { Encourage use of cleaner diesel technology through tax incentives (UK) }\end{array}$ \\
\hline
\end{tabular}


(Table 5) contd.....

\begin{tabular}{|c|c|}
\hline Policy Area & $\begin{array}{l}\text { Approaches/Solutions/Instruments } \\
\text { Symbols: } \mathbf{J}=\mathbf{J} \text { Japan, } \mathbf{U K}=\mathbf{U K}, \mathbf{N}=\text { Netherlands, } A=\text { Australia, } \mathbf{U S}=\mathbf{U S A}, \mathrm{C}=\mathrm{Canada}\end{array}$ \\
\hline 0Land Use and Living Environment & $\begin{array}{l}\text { Good quality residence and housing through tax and financial measures (J) } \\
\text { Promotion of barrier free buildings and passage to buildings (J, US) } \\
\text { Enforcement of standards for automobile exhaust emissions (J, US) } \\
\text { Beautiful landscapes and plentiful greenspace (J) } \\
\text { Improve shopping environment and create better convenience (J) } \\
\text { Early introduction of public transportation to new housing/development area (UK) } \\
\text { Revise planning guidance on new housing devt and land use planning for regional/local level; end to } \\
\text { mushrooming of out of town shopping centres (UK) } \\
\text { Transport policy and plans based on national spatial planning policy (N) } \\
\text { Integrate land use planning and transport infrastructure provision based on National Land Transport Plan } \\
\text { (A) } \\
\text { Explore collaborative efforts to establish supporting transportation management and land use planning } \\
\text { frameworks (N, US) }\end{array}$ \\
\hline Institutional Changes/Policy Management & $\begin{array}{l}\text { Decentralize traffic, transport and land use policy and planning }(\mathrm{N}) \\
\text { Private sector (transport operators) to control tactical and operational level of public transport services; } \\
\text { local govt define services at the strategic level (N) } \\
\text { Tranportation ministry links with other policy fields including environment, spatial planning, economy, } \\
\text { health care and education (N) } \\
\text { Address and deliver infrastructure spending within a new strategic framework - involving all levels of } \\
\text { government and private sector (A) } \\
\text { Collaborate with industry, all levels of govt and academia on options for road pricing and urban transit } \\
\text { infrastructure (C) } \\
\text { Nurture innovation clusters for research and technological application (C) } \\
\text { Work with community of disabled, senior citizens and transport industry to develop a long-term, multi- } \\
\text { modal federal strategy for enhancing accessibility of the national transportation system (C) } \\
\text { Deregulation in transport industry (J, N) }\end{array}$ \\
\hline
\end{tabular}

strong in countries with relatively centralized set-up and/or those with a strong spatial planning orientation. In the case of Australia, transportation and land-use integration has been solidified under the auspices of the "National Charter of Integrated Land-use and Transport Planning", a high-level agreement endorsed in 2003 by the transport and planning Ministers with the collaboration of all states, territories and the Commonwealth (Australian) Government. Such charter gives teeth to the commitment for land-use and transport planning that will reduce the need for travel, making it easier and safer for people to access services, providing a choice of travel modes, among others. Land-use planning and promotion of a better living environment are emphasized in Japan, the Netherlands, Australia and the UK. However, the orientation of such integration in providing a secure and accessible mobility for the older population is better articulated in Japan than elsewhere. Notwithstanding, the solutions identified by other countries in terms of conscious effort to link transportation with housing and land-use development through systematic planning and coordination would have a profound impact on older people's mobility in the long-term.

Lastly, institutional reforms and policy management are critical in seeing through the effective implementation of adopted approaches and solutions. The reforms vary between countries depending on the level and degree of coordination happening at present. For instance, in Netherlands there are important shifts in institutional coordination in terms of deregulation of the transport industry as well as decentralizing responsibilities of the national government to the various sub-national entities. Institutional integration is emphasized in Canada and Australia in terms of greater collaboration of the public sector with industry groups. Noteworthy also is Canada's effort to work with various sectors including the disabled and senior community to develop a long-term strategy for enhancing accessibility of the national transport system. As mentioned earlier, Canada has also posed itself to develop a strong research and development in the transportation field that will muster the resources of the academic, industry and government sectors.

\section{SUMMARY AND IMPLICATIONS FOR CANADIAN POLICY}

This study provided a general framework for analyzing and comparing country transport policies as they impact on the demographic aging issues. Policy context and contents were the main focus of the framework application to investigate the transport policies of the six selected countries. The paper highlighted how the country's policy context and motivations strongly influence the selection of specific strategies and approaches to deal with mobility issues. In so doing, this study demonstrated the importance of policy motivations and institutional set-up of countries in the choice and articulation of transport policy objectives and the respective approaches and solutions to achieve them. General policy objectives may be the same across countries but can be differently articulated and implemented, as they are reflections of these motivations and governance structures. These generalizations find evidence in a country's orientation towards the aging issues. The nature and degree to which countries recognize the impact of demographic aging are reflected in their choice of transport policy actions. Among the countries studied, Japan has placed the aging issue as a central backdrop in 
its transport policy framework and this focus has shown greater sensitivity of its transport policy to elderly mobility. For instance, the focus on sustainable development in recent years has led countries to veer away from a car-oriented urban mobility and instead place a greater deal of attention to public transit. In Japan, though, while having the environmental goal in mind, there is a general motivation of making public transit accessible and comfortable to use as part of the country's efforts towards creating a living environment conducive to an increasingly aging society.

This paper also showed the breadth of concerns that directly and indirectly impact on older people's mobility and the possibilities of solutions that can be adopted depending on a country's policy orientation. These include policies dealing with: a] travel modalities and the economic instruments that would promote them; b] investments on transport infrastructure and systems that enhance driving or the use of alternatives to the car; c] technological advances that improve the travel mode and the transport environment; d] the strong linkage between transportation and land-use planning as it impacts on the living environment of older people; and e] institutional reforms and policy management initiatives that will enhance and help achieve program formulation and implementation. These policy areas may serve as a general checklist in the continuing review and rethinking of transport policies especially in aging countries not only in developed countries where the issues are urgent but also in developing countries where the challenges will be more felt in the coming decades.

Canada's current vision and policy framework for transportation has acknowledged a diverse and aging population as one of the forces that will shape economy and society - a societal change that transportation policy has to adapt in the future alongside the other modern challenges of "continentalism, globalization, environmentalism, urbanization and the high technology explosion" [42]. Moreover, it has indicated that it will work with the disabled, senior citizens and transportation industry to develop a "long-term, multi-modal federal strategy for enhancing the accessibility of the national transportation system". While this is undoubtedly a step in the right direction, there is a need to go beyond the seeming mindset of providing accessible infrastructure to deal with the mobility needs of older people and to revisit its policy stance on other policy areas that would have both direct and indirect impact on the mobility of its older population. There have been significant efforts in other countries (especially in the US) to allow for empirical and policy-based research to develop a better understanding of the transport implications of an aging society. For instance, the US Transport Research Board has identified the aging population as one of the 14 critical challenges facing users or providers of current and future transportation services [43]. In Japan, the demographically oldest country in the world, population aging has been the focal point to guide the development of policies and programs concerning land, infrastructure and transport development [33]. Indeed, the shift in focus from a narrow elderly-disability notion to a wider point of view of demographic process of aging affecting transportation system will aid in promoting innovations in meeting mobility needs of elderly people of diverse health and income status. There is a sense that the elderly in the future (at least in the developed world) would be healthier and not necessarily poor to be- come a social welfare target. Appropriate policies and transport services for this growing segment of the population will create opportunities for public and private mobility services or industries. For example, while policies have concentrated on improving roads for older drivers and screening drivers to identify who should stop driving, policies to improve alternative mobility services provision (by public or private sector) are lacking.

Canadian policymakers would also need to support more policy-based researches and empirical studies on aging and transportation as knowledge on this area remain scanty. The problem of dearth and unavailability of data in Canada to undertake transport research deserves emphasis as this provides the greatest impediment to evidence-based policy research. While the inclusion of more transportation questions in the 2005 General Social Survey (GSS) is a step in the right direction, it must be sustained and expanded in the future to capture more questions on personal travels. The other option is to undertake a Canada-wide transport survey similar to the nationwide Personal Transportation Survey (NPTS) being carried out in the US every 5 to 7 years, to gain a more holistic characterization of Canadian travel behaviour and to allow for interregional comparisons. In addition, regional travel surveys (e.g. Transportation Tomorrow Survey in the Greater Toronto Area) should also be more sensitive to elderly travel behaviour by including travel activities that the elderly undertake (e.g. entertainment, socialize with friends, shopping, medical visits, etc.). Moreover, questions regarding health status or physical limitations could be included (e.g. as in the case of London Travel Survey; [44]) to understand the extent of coping with travel in the face of declining travel abilities and road safety risks. Relatedly, Evans [45] commented that "the older driver problem may be one of reduced mobility more than one of reduced safety". Whether this is true or not today or in the future remains a big question. Canadian accident data has been pointed out to be lacking in many respects and it is about time that dependence on US analysis be addressed by building up a sound data base on road accident exposure including better exposure data that relies on actual distance traveled (versus license ownership) as well as proper categorization of exposure among elderly groups (i.e. from $65+$ to $65-74,75-84,85+$ ) [46]. In the meantime, there is an urgent call for aging and transport studies to be conducted using data available not only to gain insights on the changing mobility behaviour of the present and the next generation of elderly population but also to provide suggestions that will guide future efforts to improve travel survey design and collection.

Interdisciplinary researches are also needed. In the US, there are plans to include the private sector and disciplines not usually included in the aging policy community such as business, urban planning, transportation, housing, environment, and law for a "Boomer Interdisciplinary Research" [5]. Canada seems to be well poised in undertaking similar effort given its vision to develop transportation as an innovative knowledge-based sector and the already well-placed government-launched Canada's Innovation Strategy. Notwithstanding, other complementary research programs can be put together to look into transport-related issues surrounding the more diverse aging boomers. 


\section{ACKNOWLEDGEMENTS}

This project was supported financially by grant DEC\#SCO from GEOIDE (Geomatics for Informed Decisions), one of Canada's Networks of Centers of Excellence. The authors are also grateful for comments and suggestions given by the anonymous referees.

\section{REFERENCES}

[1] United Nations. Report of the United Nations Second World Assembly on Aging. (available from the web http://www.un.org/esa/ socdev/aging/waa last accessed September 2007), 2002.

[2] European Conference of Ministers of Transport (ECMT). Transport and Ageing Population. (available from the web http://www. cemt.org/pub/pubpdf/00RT112e.pdf. last accessed September 2007), 2002

[3] Organisation for Economic Cooperation and Development (OECD), Ageing and Transport: Mobility Needs and Safety Issues. Paris: OECD, 2001.

[4] R. W. Cobb and J. F. Coughlin, "Transportation Policy for an Aging Society: Keeping Older Americans on the Move", in 1999 Annual Meeting of the Transportation Research Board, CD-ROM, 1999.

[5] P. Hodge. Living Younger Longer: Boomer Challenges. Policy Committee for 2005 White House Conference on Aging, (available from the web www.genpolicy.com/articles/2005 last accessed September 2007), 2004.

[6] D. A. Hensher, "Some Insights into the Key Influences on Tripchaining Activity and Public Transport Use of Seniors and the Elderly", Int. J. Sustain. Transport., vol. 1, no. 1, pp. 53-68, January 2007.

[7] A. Paez, D. M. Scott, D. Potoglou, P. Kanaroglou, and K. B. Newbold, "Elderly Mobility:Demographic and Spatial Analysis of Trip Making in the Hamilton CMA, Canada", Urban Studies, vol. 44, no. 1, pp. 123-146, 2007.

[8] T. F. Golob and D. A. Hensher, "The trip chaining activity of Sydney residents: A cross section assessment by age-group with a focus on seniors", J. Transport. Geogr., vol. 15, no. 4, pp. 298-312, 2007.

[9] J. Zhang and A. Fujiwara, "Representing household time allocation behavior by endogenously incorporating diverse intra-household interactions: A case study in the context of elderly couples", Transport. Res. Part B: Methodol., vol. 40, no. 1, pp. 54-74, 2006.

[10] Owsley.C., "Clinical and research issues in older drivers: Future directions", Alzheimer Dis. Assoc. Disord., vol. 11, pp. 3-7, 1997.

[11] A. Siren and L. Hakamies-Blomqvist, "Private car as the grand equaliser?", Transport. Res. Part F: Traffic Psychol. Behav., vol. 7, no. 2, pp. 107-118, 2004.

[12] G. Li, E. R. Braver, and L. Chen, "Fragility versus excessive crash involvement as determinants of high death rates per vehicle-mile of travel among older drivers", Accid. Anal. Prev., vol. 35, no. 2, pp. 227-235, 2003.

[13] D. V. Collia, J. Sharp, and L. Giesbrecht, "The 2001 National Household Travel Survey: A look into the travel patterns of older Americans", J. Safety Res., vol. 34, no. 4, pp. 461-470, 2003.

[14] TRB, "Transportation in an Aging Society: A Decade of Experience", in Transportation Research Board Conference Proceedings 27, 1999.

[15] S. Rosenbloom, "Sustainability and automobility among the elderly: An International Assessment" Transportation, vol. 28, pp. 375-408, 2001.

[16] K. Doi, M. Kii, and H. Nakanishi, "Development of a QOLPerformance Indicator as an Alternative Accessibility Measure", in 9th International Conference on Computers in Urban Planning and Urban Management, 2005.

[17] WHO. Active ageing: a policy framework. World Health Organization, Geneva, Switzerland. (available from the web http://whqlibdoc.who.int/hq/2002/WHO_NMH_NPH_02.8.pdf. last accessed: September 2007], 2002.

[18] J. F. Coughlin, "Invention vs Innovation: Technology and the Future of Aging", Aging Today, vol. 27, no. 2, pp. 3-4, 2006.

[19] S. A. McDaniel, "Toward disentangling policy implications of economic and demographic changes in Canada's aging population", Can. Public Pol., vol. 24, no. 4, pp. 491-510, 2003.
[20] E. M. Gee, "Voodoo Demography, Population Aging and Social Policy", in The Overselling of Population Aging: Apocalyptic Demography, International Challenges and Social Policy. E. M. Gee and G. Gutman, Eds. UK: Oxford University Press, 2007.

[21] S. Bush, "Forecasting 65+ Travel: An Integration of Cohort Analysis and Travel Demand Modeling", in Transportation Research Board Annual Meeting, CD ROM, 2005.

[22] K. B. Newbold, D. M. Scott, J. E. L. Spinney, P. Kanaroglou, and A. Paez, "Travel behavior within Canada's older population", $J$. Transport. Geogr., vol. 13, no. 4, pp. 340-351, 2005.

[23] D. M. Scott, K. B. Newbold, J. E. L. Spinney, R. G. Mercado, A Paez, and P. Kanaroglou, Changing mobility of elderly urban Canadians, 1992-1998. 2005. (available from the web http://sciwebserver.science.mcmaster.ca/cspa/papers/ last accessed September 2007], 2005.

[24] R. G. Mercado, A. Paez, and K. B. Newbold, Benchmarking Transport Policy in an Aging Society in Ontario, Canada, in Proceedings of the 86th World Conference on Transport Research CDROM, 2007.

[25] K. Doi, Benefits of Consolidation: Japan's New Ministry of Land, Infrastructure and Transport. (available from the web http://www.apta.com/services/intnatl/intfocus/japancon.cfm last accessed September 2007), 2005.

[26] A. Van der Hoorn and B. Luipen. National and Regional Transport Policy in the Netherlands: A Short Introduction. Association for European Transport. (available from the web http://www.rwsavv.n1/pls/portal30/docs/9860.PDF last accessed September 2007), 2003.

[27] VROM. Development Planning”, Netherlands Ministry of Housing, Spatial Planning and Environment. (available from the web http://international.vrom.nl/pagina.html?id=9225. last accessed September 2007), 2005.

[28] Transport Canada. Transportation in Canada. Government of Canada (available from the web www.tc.gc.ca/pol//en/report/ anre1996/tc96_chapter_1.htm. last accessed September 2007), 1996.

[29] B. F. D. Barrett, "Decentralization in Japan: Negotiating the Transfer of Authority", Japanese Studies, vol. 20, no. 1, pp. 33-48, 2000.

[30] I. Docherty, J. Shaw, and M. Gather, "State intervention in contemporary transport", J. Transport. Geogr., vol. 12, no. 4, pp. 257264, 2004.

[31] DTRS, AusLink White Paper: Building our National Transport Future. Canberra: Australia Department of Transport and Regional Services, 2004.

[32] R. Raicu, D. Scrafton, and M. Taylor, "AusLink: A New Approach to Intergovernmental QArrangements for land Transport Funding", in Proceedings of the 40th Annual Conference of the Canadian Transportation Research Forum, 2005.

[33] MLIT, White Paper on Land, Infrastructure and Transport in Japan. Tokyo: Japan Ministry of Land, Infrastructure and Transportation, 2002.

[34] DETR, Integrated Transport White Paper: A New Deal for Transport. London: UK Department of Environment, Transport and Regions, 1998.

[35] MVW, Mobility Policy Document (Nota Mobiliteit). Hague: Ministerie van Verkeer en Waterstaat (Ministry of Public Transport, Public Works and Water Management), The Netherlands, 2004.

[36] USDOT, Strategic Plan 2003-2008: Safer, Simpler, Smarter Transportation Solutions. Washington: United States Department of Transportation, 2003.

[37] T. Grayling, "Whatever happened to Integrated Transport?", Political Quarterly, vol. 75, no. 1, pp. 26-33, 2007.

[38] C. Gertz, "Lessons from a landmark US policy for transportation, land use and air quality, and implications", Int. Social Sci. J., vol. 55, no. 2, pp. 307-317, 2003.

[39] CTARP, Vision and balance: Canada Transportation Act Review Panel. Ottawa: Ministry of Public Works and Government Services Canada, 2001.

[40] N. Assinder, UK Politics - Prescott unveils back-to-buses policy. BBC On-line news, 20 July (available from the web http://news.bbc.co.uk/1/hi/uk_politics/136096.stm last accessed September 2007), 1998.

[41] DfT, "The Future of Transport: a network for 2030," Department for Transport (available from the web http://www.dft.gov. uk/about/strategy/whitepapers/fot/ last accessed September 2007), 2004. 
[42] Transport Canada, Straight Ahead: A Vision for Transportation in Canada. Ottawa: Government of Canada, 2003.

[43] A. E. Pisarski, "Prescriptions for research: reviewing the history of TRB's critical issues in transportation" TR News vol. 226, pp. 3035, 2003.

[44] J. D. Schmocker, M. A. Quddus, R. B. Noland, and M. G. H. Bell, "Estimating trip generation of elderly and disabled people - analysis of London data", Manag. Public Policy, pp. 9-18, 2005.
[45] L. Evans, "Older driver involvement in fatal and severe traffic crashes", Social Sci, vol. 43, no. 6, pp. 186-193, 1988.

[46] J. K. Caird, Anticipating the Effects of Canada's Aging Population on Older Driver Safety and Mobility. Calgary: Van Horne Institute for Transportation Studies, 2000. 